\title{
Editorial
}

\section{The Code of Ethics for Preschool Teachers, Traditional Moral Values, and Protection of Children's Privacy}

\author{
Hana Song \\ 영유아교사윤리강령, 전통적인 도덕적 가치, \\ 그리고 아동의 개인 정보 보호 \\ 송하나 \\ 성균관대학교 아동청소년학과
}

Department of Child Psychology and Education, Sungkyunkwan University, Seoul, Korea

한 사회에서 윤리적이고 도덕적인 기준을 지키고 실천하는 것은 단순한 규정이나 법규 준수 그 이상의 의미를 가진다. 일반적으로 윤리 규정은 개인의 비윤리적 행위나 대인 간 충 돌을 방지하는 역할을 한다. 그러나 아동을 양육하고 교육하 는 현장에서는 명문화된 규정 이상의 내재화된 윤리적 가치 가 부모와 교사에게 요구되는 것 같다. 그 이유는 '하지 말아 야 할 일은 하지 않았어' 혹은 '내가 한 일이 아니야' 등의 소 극적인 자세로는 최근 어린 아동들을 대상으로 벌어진 불미 스러운 사건에 대한 근본적인 성찰이 어렵기 때문이다. 이런 점에서, 본 호에 수록된 영유아교사윤리강령에 대한 리뷰를 살펴볼 필요가 있다.

윤리강령에 대한 논의에서 무엇보다 눈여겨 볼 부분은 ‘해로운 일을 하지 않는 것'과 ‘이로운 일을 하는 것'에 대한 것이다. 재능 있는 인재를 교육하는 일은 중국의 철학자인 맹자가 군자의 세 가지 즐거움 중 하나로 꼽을 만큼 평생 보 람 있고 즐거운 일이다. 그러나 이러한 교육의 가치와 즐거 움이 해악을 끼치지 않는 정도의 방어적이고 소극적인 차원 에서 실현되기는 어려울 것이다. 그보다는 '이로운 일'을 한 다는 마음으로 아동들 각각의 특성과 잠재력을 고려하여 건 강하게 재능을 꽃피울 수 있도록 최적의 발달 환경을 제공

Corresponding Author: Hana Song, Editor-in-Chief Department of Child Psychology and Education, Sungkyunkwan University, 25-2, Sungkyunkwan-Ro, Jongno-Gu, Seoul 03063, Korea

E-mail: jni4ever@skku.edu
하는 것이 필요하다. 따라서 해를 주지 않는 것을 다행으로 여겨야 하는 현실이 안타깝게 생각된다.

현대의 윤리강령과는 차이가 있지만, 이번 호에 게재된 서평에서 추천하고 있는 소학의 교훈은 적극적인 교사 윤리 의 실천이 시대에 관계없이 요구되는 가치임을 보여주고 있 다. 소학의 저자인 주희는 좋은 인격 형성이 일상 생활에서 예와 윤리를 기반으로 한 대인 관계를 통해 이루어진다고 하 였다. 다시 말해, 윤리와 도덕은 탁상공론이 아니라 실생활 에서 실천을 통해 실현될 수 있는 가치라는 것이다. 교사는 교사대로, 부모는 부모대로, 기관은 기관대로 윤리적 역할과 책임을 다하려는 마음이 중요할 것이다.

또한 윤리적 기준은 인간의 권리와 밀접한 관계가 있다. 이번 호에 게재된 유치원 홈페이지 운영에 관한 연구는 개인 정보 보호와 관리에 아직 부족한 부분이 있음을 언급하고 있 는데, 이러한 문제를 아동권리 및 윤리적 차원에서 생각해볼 필요가 있다. 온라인이나 SNS를 이용하는 것은 유치원 행사 나 활동을 부모에게 공지하는 효율적 방법일 것이다. 하지만 아동의 사진이나 동영상이 SNS나 유튜브를 통해 여러 사람 들에게 공유되는 것을 보면 때로 불편한 마음을 금할 수 없 다.

(C) The Korean Association of Child Studies

This is an Open Access article distributed under the terms of the Creative Commons Attribution Non-Commercial License (http:// creativecommons.org/licenses/by-nc/4.0) which permits unrestricted noncommercial use, distribution, and reproduction in any medium, provided the original work is properly cited. 
귀여운 아이의 모습을 여러 사람에게 보여주고 싶은 마음 을 갖는 것을 비윤리적이라고 할 수는 없다. 그러나 너무 어 린 아동들은 이러한 공유에 대해 스스로 동의나 거부의사를 표현할 수 없다는 것을 고려해야 한다. 유튜브에 동영상을 공개하는 것은 아동의 생김새, 연령대, 성별, 생일, 가족 관계 등 개인 신상 정보를 그대로 노출하는 결과를 가져올 수 있 다. 더 많이 공유될수록 개인정보의 노출 위험은 커지고 아 동의 사생활 보호는 어려워지기 마련이다. 아동을 안전하게 보호하는 일은 어른들의 의무이자 아동들의 권리이다. 따라 서, 부모나 교사가 아동을 온라인과 SNS상에서 보호하는 것 은 윤리를 실천하는 일이 될 수 있을 것이다.

마지막으로, 이번 호의 구성을 간략히 소개하자면, 리뷰 2 편과 연구논문 12 편, 그리고 서평 1 편이 수록되어 있다. 앞 서 언급한 영유아교사 윤리강령 외에, 아동과 청소년 정책에 대한 리뷰가 소개되고 있다. 또한 연구논문들은 주로 부모자 녀 관계와 아동 발달, 유아와 청소년 또래관계, 그리고 영유 아용 측정 도구 개발이라는 세 가지 주제를 다루고 있다. 무 엇보다 앞서 언급했듯이, 이번 호에는 조선시대 아동교재로 사용했던 소학에 대한 서평이 실려 있다.

학술지는 엄격히 검증된 연구 결과의 보고와 학자들 간의 학술적 정보 교류라는 목적에 충실할 필요가 있다. 그러나 교육자, 상담가, 행정가, 부모, 그리고 일반인들에게 유용한 정보를 전달하고 그들이 의견을 나눌 수 있는 장을 마련하는 것도 학술지가 사회에 기여하는 생각된다. 따라서, 서평이나 시론(commentary), 사례 보고(case report)의 증가는 환영할 만한 일이다. 앞으로 비학술적 원고의 투고가 늘어나길 바란 다.

In a society, complying with and practicing ethical and moral standards has more to do with obeying regulations and laws. Generally, ethical rules play an important role in preventing unethical behaviors or interpersonal conflicts. However, it appears that in the field of childrearing and education, the internalized ethical values of parents or teachers are more important than specified rules. This is because it is difficult to assimilate bad news and solve problems regarding victimized children with a passive attitude such as, "I do not do that" or "It should not be done." Therefore, it is recommended that the review of the code of ethics for preschool teachers in this issue of the journal be read.

Primarily, I advise you to study the discussion on "Not doing harmful activities." vs. "Performing supportive and profitable activities." Teaching talented children is one of the three delights of the superior man, said Mencius, a Chinese philosopher. Teaching should be a rewarding and delightful experience for a lifetime. However, the joy of education cannot be realized with a defensive and passive attitude such as, "Not harming children." Rather, it is necessary to provide children with optimal developmental environments that are appropriate for the characteristics and potential of each child.

Although it differs from the code of ethics, a book review of Sohak (elementary learning) in this issue illustrates that the active practice of teachers' code of ethics is valued regardless of the age and times. Zui Xi, the author of Sohak notes that good personality can be established through interpersonal relationships based on courtesy and ethics in everyday life. In other words, ethics and morality should be practiced within the real context of interpersonal interactions. It seems that fulfilling roles and ethical responsibilities as teachers, parents, institutions, and children is required.

In addition, ethical standards are closely related to human rights. In this issue, a study on the management of Kindergarten websites reported that personal information protection and safety management have yet to reach a satisfactory level in terms of ethical standards. Social networking and the internet are effective tools to inform parents about events and activities. However, I cannot help feeling uncomfortable whenever I see children's photos and videos shared on Social Networking Sites (SNS) or YouTube.

Though it might not be unethical for parents and teachers to want to share photos of their children with others, we should remember that infants and young children cannot express their agreement or disagreement with this distribution. Sharing videos on YouTube could reveal significant personal information such as a 
child's appearance, age, gender, birth date, and family relationships. The more they share, the greater the threat of personal information exposure, placing the safety and protection of children's privacy at risk. It is a child's right as well as the responsibility of adults to protect children. Therefore, it is necessary for parents and teachers to protect children online and on SNS

This issue includes two reviews and 12 research papers. Two reviews on teachers' code of ethics and child and youth policies are introduced, while the 12 research papers primarily deal with three topics: parent-child relationships and child development, peer relationships during early childhood and adolescence, and the development and revision of scales for infants, toddlers, and preschoolers. Finally, it is interesting to note that this issue contains a book review of Sohak.

Academic journals have their own aims of presenting valid and reliable research findings and exchanging scientific empirical information among scholars. However, it is also important to deliver useful and applicable academic information to educators, counselors, practitioners, administrators, parents, and others, and to communicate with them. Thus, I believe that open communication with the public is a means for our journal to assume social responsibility. Therefore, we welcome book reviews, commentaries, and short case reports. I hope that submissions of non-academic manuscripts will increase in the future.

Hana Song, Editor-in-Chief of the Korean Journal of Child Studies.

\section{Conflict of Interest}

No potential conflict of interest relevant to this editorial was reported.

\section{ORCID}

Hana Song http://orcid.org/0000-0002-7745-7303 